\title{
KETAHANAN PANGAN RUMAH TANGGA BERHUBUNGAN DENGAN STATUS GIZI ANAK USIA DI BAWAH DUA TAHUN (BADUTA) DI KELURAHAN KEBON KALAPA, KECAMATAN BOGOR TENGAH, JAWA BARAT
}

\author{
Household Food Security is Associated with Nutritional Status of Children Under Two Years Old \\ in Kebon Kalapa, Central Bogor Subdistrict, West Java \\ Nur Handayani Utami, Dwi Sisca KP \\ Pusat Teknologi Intervensi Kesehatan Masyarakat, Balitbangkes, Kemenkes RI, \\ Jl. Percetakan Negara No.29. Jakarta \\ E-mail: nur_handayani80@yahoo.com
}

\begin{abstract}
Household food security in some previous studies were found associated with the occurrence of malnutrition in children. This study aimed to analyze the relationship between household food security with stunting in children under 2 years of age (6-23 months) in Kebon Kalapa Village, Central Bogor. This was a cross-sectional study in Kebon Kalapa, Central Bogor Subdistrict. A total of 216 children under two years of age (6-23 months) and their mother were selected as samples in this study. The dependent variable in this study was the nutritional status of children (HAZ), whereas the main independent variables, was household food security. Food security was measured using an instrument called Household Food Insecurity Access Scale (HFIAS). Results showed that more than half of the households had food secure (63\%), and other households which were classified as mild, moderate and severe categorizes of food insecure were $17 \%, 11 \%$ and $9 \%$, respectively. The study concluded that household food security is a risk factor for stunted children under two years of age, where children with food insecure household were at risk of 10.9 times become stunted after corrected by the child's age, birth weight, breastmilk consumption, use of a bottle feeding, food diversity, maternal age, maternal education, maternal nutrition knowledge, food hygiene practice, father's education and father's work.
\end{abstract}

Keywords: food security, nutritional status, under-two children

\begin{abstract}
ABSTRAK
Ketahanan pangan rumah tangga dalam beberapa studi sebelumnya ditemukan berhubungan dengan terjadinya kekurangan gizi pada anak. Tulisan ini bertujuan untuk menganalisis hubungan ketahanan pangan rumah tangga dengan terjadinya pendek pada anak usia di bawah 2 tahun (6-23 bulan) di Kelurahan Kebon Kalapa, Kecamatan Bogor Tengah. Studi ini memiliki disain potong lintang dan dilakukan di Kelurahan Kebon Kalapa, Kecamatan Bogor Tengah. Sebanyak 216 anak usia dibawah dua tahun (6-23 bulan) beserta ibu nya menjadi sampel dalam penelitian ini. Variabel terikat dalam studi ini adalah status gizi anak (TB/U), sedangkan variabel bebas utama yaitu: ketahanan pangan rumah tangga. Ketahanan pangan diukur dengan menggunakan instrumen Household Food Insecurity Access Scale (HFIAS). Hasil menunjukkan bahwa lebih dari separuh rumah tangga termasuk dalam kategori tahan pangan (63\%). Di antara rumah tangga responden masih ada yang tergolong dalam kategori tidak tahan pangan tingkat ringan, sedang dan berat 17 persen, 11 persen dan 9 persen. Studi ini menyimpulkan bahwa ketahanan pangan rumah tangga merupakan risiko terhadap kejadian pendek pada baduta, dimana anak baduta dengan keluarga yang ketahanan pangan nya tidak baik memiliki resiko sebesar 10,9 kali anak badutanya menjadi pendek setelah dikoreksi oleh usia anak, berat lahir, konsumsi ASI, penggunaan dot, keragaman makanan, usia ibu, pendidikan ibu, pengetahuan gizi ibu, praktek higiene makanan, pendidikan ayah serta pekerjaan ayah.
\end{abstract}

Kata kunci: ketahanan pangan, status gizi, baduta

\section{PENDAHULUAN}

eriode kehamilan sampai dengan anak berusia dua tahun sering dikenal dengan istilah 1000 Hari Pertama Kehidupan
(HPK). Periode ini dikenal pula dengan istilah "window of opportunity" atau jendela kesempatan yang berarti bahwa kesempatan terbesar yang menentukan masa depan seorang anak terjadi pada masa ini, dimana jika 
pada masa ini terjadi kerusakan maka akan terjadi kerusakan yang permanen. Sebaliknya perbaikan gizi juga diketahui paling efektif dilakukan pada masa ini. ${ }^{1}$

Namun berdasarkan hasil berbagai survei nasional di Indonesia menunjukkan bahwa permasalahan gizi masih menjadi permasalahan kesehatan masyarakat. Di antara permasalahan gizi pada anak dibawah usia dua tahun ini stunting (pendek) merupakan masalah yang paling banyak diamati. Hal ini karena proporsi pendek pada balita yang cenderung stagnan, tidak banyak perubahan yang berarti. Proporsi balita pendek yang mengalami penurunan berdasarkan hasil Riskesdas pada tahun $2010(35,6 \%)$ dari tahun sebelumnya pada tahun $2007(37,7 \%)$ ternyata meningkat lagi pada Riskesdas 2013 menjadi 37,2 persen, menandakan bahwa belum terjadi perubahan perbaikan keadaan gizi balita di masyarakat. ${ }^{2}$

Ketahanan pangan rumah tangga didefinisikan sebagai kemampuan rumahtangga untuk bisa mengakses pangan dalam rangka memenuhi kebutuhan hidup anggota keluarganya untuk hidup sehat dan berkualitas. Beberapa studi dan analisis sebelumnya telah menemukan bahwa ketahanan pangan rumah tangga berhubungan dengan terjadinya kekurangan gizi pada anak. ${ }^{3}$

Tulisan ini bertujuan untuk menganalisis hubungan ketahanan pangan rumah tangga dengan terjadinya pendek pada anak usia di bawah dua tahun (6-23 bulan) di Kelurahan Kebon Kalapa, Kecamatan Bogor Tengah.

\section{METODE PENELITIAN}

Disain dari studi ini adalah potong lintang. Studi ini dilaksanakan di Kelurahan Kebon Kalapa Kecamatan Bogor Tengah pada tahun 2013. Sebanyak 216 anak baduta dan ibunya menjadi subyek dalam studi ini. ${ }^{4}$ Kriteria inklusi dari subyek yaitu berusia 6-23 bulan pada saat pengumpulan data dilakukan, tinggal di wilayah Kelurahan Kebon Kalapa, sehat (tidak mengalami gangguan kesehatan yang dapat mengganggu nafsu makannya) serta bersedia menjadi sampel penelitian. Sedangkan kriteria eksklusinya yaitu menderita gizi buruk, mengalami cacat/kelainan bawaan serta menderita sakit berat.

Variabel terikat dalam studi ini adalah status gizi anak, sedangkan variabel bebas utama yaitu : ketahanan pangan rumah tangga. Sementara itu yang merupakan variabel konfounding yaitu : karakteristik anak baduta (jenis kelamin, umur, berat lahir), karakteristik orangtua (usia ibu, pendidikan ibu, pekerjaan ibu, paritas ibu, pendidikan ayah dan pekerjaan ayah), konsumsi ASI 24 jam yang lalu, penggunaan botol dot setiap hari, keragaman makanan, praktek higiene makanan serta morbiditas anak. Praktek higiene makanan merupakan komposit dari kebiasaan ibu mencuci tangan ibu dan anak dengan sabun sebelum memberi makan anak, cara ibu memberikan makan anak (segera/tidak segera), kebiasaan ibu mensterilkan alat makan dan kebiasaan ibu memberikan makan anak bersama-sama dengan anak lain. Masingmasing diberikan skor dan kemudian skor tersebut dijumlahkan dan dikategorikan menjadi praktek higiene yang kurang baik, sedang dan baik. Morbiditas anak dikategorikan menjadi pernah menderita sakit (batuk,pilek, panas atau diare) selama 2 minggu yang lalu, maupun tidak pernah menderita sakit selama 2 minggu yang lalu.

Keragaman makanan terbagi menjadi keragaman bahan makanan dan keragaman pola makan. Keragaman bahan makan anak merupakan kategori keragaman bahan makan anak terhadap 8 kelompok bahan makanan ; serealia, akar dan umbi-umbian, kacangkacangan, buah dan sayuran, daging dan ikan, telur, susu dan olahannya serta lemak pada 24 jam sebelumnya. Pada usia 6-8 bulan kategori keragaman bahan makanan rendah jika hanya mengkonsumsi 0-2 kelompok bahan makanan, sedang jika mengkonsumsi 3-5 kelompok bahan makanan dan tinggi jika mengkonsumsi $\geq 6$ kelompok bahan makanan. Pada usia 9-11 bulan kategori keragaman bahan makanan rendah jika hanya mengkonsumsi 0-3 kelompok bahan makanan, sedang jika mengkonsumsi 46 kelompok bahan makanan dan tinggi jika mengkonsumsi $\geq 7$ kelompok bahan makanan. Sedangkan pada usia 12-23 bulan kategori keragaman bahan makanan rendah jika hanya mengkonsumsi 0-4 kelompok bahan makanan, sedang jika mengkonsumsi 5-6 kelompok bahan makanan dan tinggi jika mengkonsumsi $\geq 7$ kelompok bahan makanan.

Keragaman pola makan merupakan kategori keragaman pola makan anak terhadap 8 kelompok bahan makanan pada 7 hari 
sebelumnya. Tiap kelompok bahan makanan diberi skor 0 bila tidak dikonsumsi selama 1 minggu sebelumya, +1 bila dikonsumsi sebanyak 1 sampai 3 kali, +2 bila dikonsumsi sebanyak 4 kali atau lebih. Kemudian skor ini dijumlahkan. Pada usia 6-8 bulan kategori keragaman pola makanan rendah jika skor keragaman pola makan $0-6$, sedang jika skor keragaman pola makan 7-9 dan tinggi jika skor keragaman pola makan $\geq 10$. Pada usia 9-11 bulan kategori keragaman pola makanan rendah jika skor keragaman pola makan 0-8, sedang jika skor keragaman pola makan 9-12 dan tinggi jika skor keragaman pola makan $\geq$ 13. Sedangkan pada usia 12-23 bulan kategori keragaman pola makanan rendah jika skor keragaman pola makan 0-11, sedang jika skor keragaman pola makan 12-13 dan tinggi jika skor keragaman pola makan $\geq 14 .^{5-7}$

Data dikumpulkan oleh enumerator terlatih dengan menggunakan pre tested questionaires. Status gizi anak diukur dengan menggunakan timbangan digital dan pengukur panjang badan.,9 Konsumsi ASI dan keragaman kelompok bahan makanan diukur dengan menggunakan metode food recall 24 jam. Keragaman pola makan didapatkan dengan metode kualitatif $F F Q$ selama 7 hari terakhir.

Status gizi anak dinilai berdasarkan standar pengukuran antropometri WHO (2005) dengan menggunakan indeks Tinggi Badan menurut umur (TB/U). Indeks TB/U dikategorikan menjadi pendek ( $z$ skor $<-2$ SD) dan normal ( $z$ skor $\geq-2 \mathrm{SD}$ ).
Ketahanan pangan rumah tangga diukur dengan menggunakan instrumen Household Food Insecurity Access Scale (HFIAS). ${ }^{10}$ Kuesioner terdiri dari sembilan pertanyaan yang mewakili tingkat umum peningkatan keparahan kerawanan pangan (akses) dan sembilan "frekuensi kejadian" pertanyaan yang diminta sebagai tindak lanjut dari setiap pertanyaan kejadian untuk menentukan seberapa seringnya terjadi. Frekuensi dari kejadian hal yang ditanyakan, dilewati jika responden menyatakan tidak mengalami hal yang ditanyakan dalam empat minggu atau 30 hari sebelumnya. Kategori ketahanan pangan rumah tangga terbagi menjadi tiga yaitu tahan pangan, rawan pangan ringan, rawan pangan sedang dan berat.

Analisa hubungan antara status gizi dengan ketahanan pangan rumah tangga dan keragaman makanan anak dilakukan dengan menggunakan regresi logistik karena outcome yang diteliti merupakan kategori.

\section{HASIL}

Gambar 1 menunjukkan sebaran rumah tangga responden berdasarkan kategori tingkat ketahanan pangan. Dapat diketahui bahwa lebih dari separuh rumah tangga termasuk dalam kategori tahan pangan. Di antara rumah tangga responden masih ada yang tergolong dalam kategori tidak tahan pangan tingkat berat.

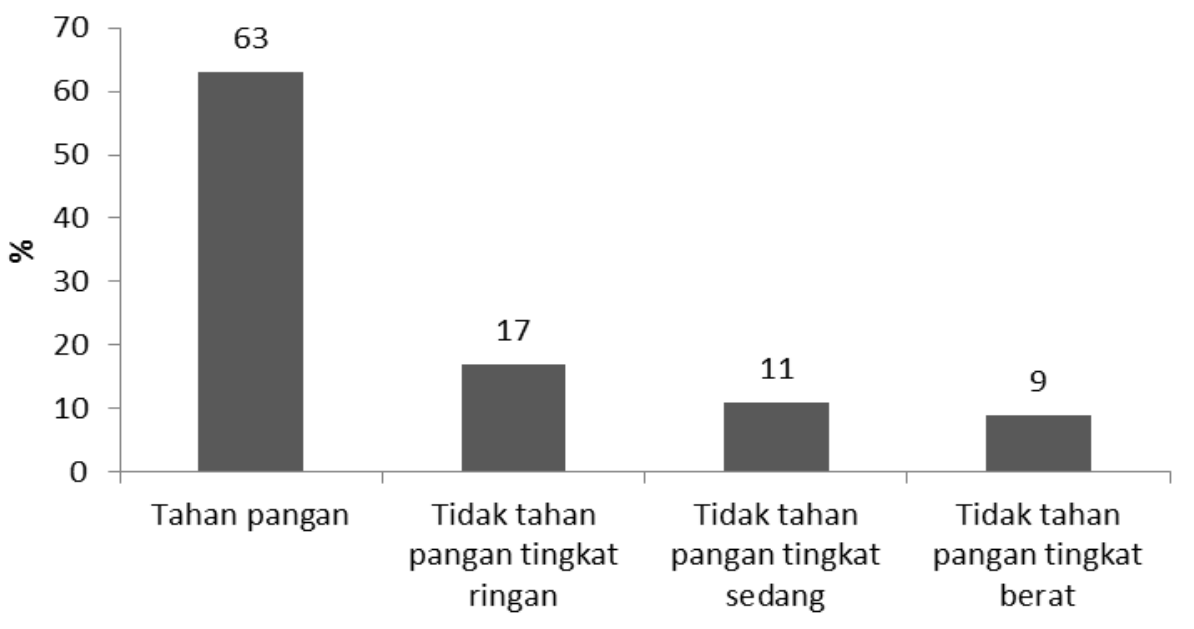

Kategori ketahanan pangan keluarga

Gambar 1

Sebaran Rumah Tangga Responden Berdasarkan Kategori Ketahanan Pangan 
Sebaran rumah tangga responden berdasarkan instrumen ketahanan pangan (HFIAS) dapat dilihat pada Gambar 2. Terdapat 3 domain utama yang dinilai dari instrumen HFIAS yaitu kecemasan dan ketidakpastian akan persediaan makanan di rumah tangga, rendahnya kualitas (termasuk variasi dan pilihan) makanan di rumah tangga dan kekurangan asupan makan dan konsekuensi fisik yang terjadi. Tiga domain ini kemudian dijabarkan lagi dalam 9 pertanyaan.

Hasil menunjukkan bahwa lebih dari sepertiga rumah tangga responden $(40,2 \%)$ pernah mengalami kekhawatiran akan kekurangan makanan dalam kurun waktu 4 minggu terakhir. Sebesar 22,4 persen rumah tangga pernah tidak bisa makan makanan yang diinginkan karena kekurangan uang. Sebesar 21,4 persen rumah tangga pernah membatasi jenis makanan yang dimakan karena kekurangan uang. Sebanyak 16,8 persen rumah tangga harus makan makanan yang tidak disukai karena kekurangan uang. Sebesar 17,8 persen rumah tangga harus makan dengan porsi lebih sedikit. Sebesar 14,9 persen rumah tangga pernah mengurangi frekuensi makan dalam sehari karena kekurangan uang. Satu dari 10 rumah tangga responden pernah mengalami tidak adanya makanan sama sekali di rumah karena kekurangan uang. Masih terdapat rumah tangga responden yang tidur dalam keadaan lapar $(7,5 \%)$ dan bahkan tidak makan sama sekali pada satu hari karena kekurangan uang $(6,5 \%)$.

Gambar 3 menyajikan sebaran status pendek baduta berdasarkan tingkat ketahanan pangan rumah tangga. Gambar tersebut menunjukkan bahwa terdapat kecenderungan bahwa dengan semakin baik tingkat ketahanan pangan rumah tangga baduta maka baduta tersebut cenderung tidak pendek.

Hasil menunjukkan bahwa berdasarkan karakteristik baduta, proporsi anak pendek lebih besar pada anak dengan usia 12-23 bulan, perempuan, berat badan lahir rendah, tidak pernah sakit 2 minggu terakhir, mengkonsumsi ASI 24 jam yang lalu, tidak menggunakan botol dot setiap hari, keragaman makanan rendah serta keragaman pola makan sedang. Sementara itu berdasarkan karakteristik orangtua dan rumahtangga, proporsi anak pendek lebih besar pada baduta dengan usia ibu > 35 tahun, paritas ibu > 3 anak, pendidikan ayah dan ibu rendah, ibu sebagai IRT, praktek higiene makanan sedang, pengetahuan gizi ibu baik, serta pekerjaan ayah sebagai buruh.

Tabel 1 juga menunjukkan bahwa terdapat satu variabel yang secara signifikan berhubungan dengan status gizi pendek anak baduta, yaitu penggunaan botol dot setiap hari $(p=0,01)$. Anak yang tidak menggunakan botol dot setiap hari lebih banyak yang pendek dibandingkan dengan anak yang menggunakan botol dot setiap hari.

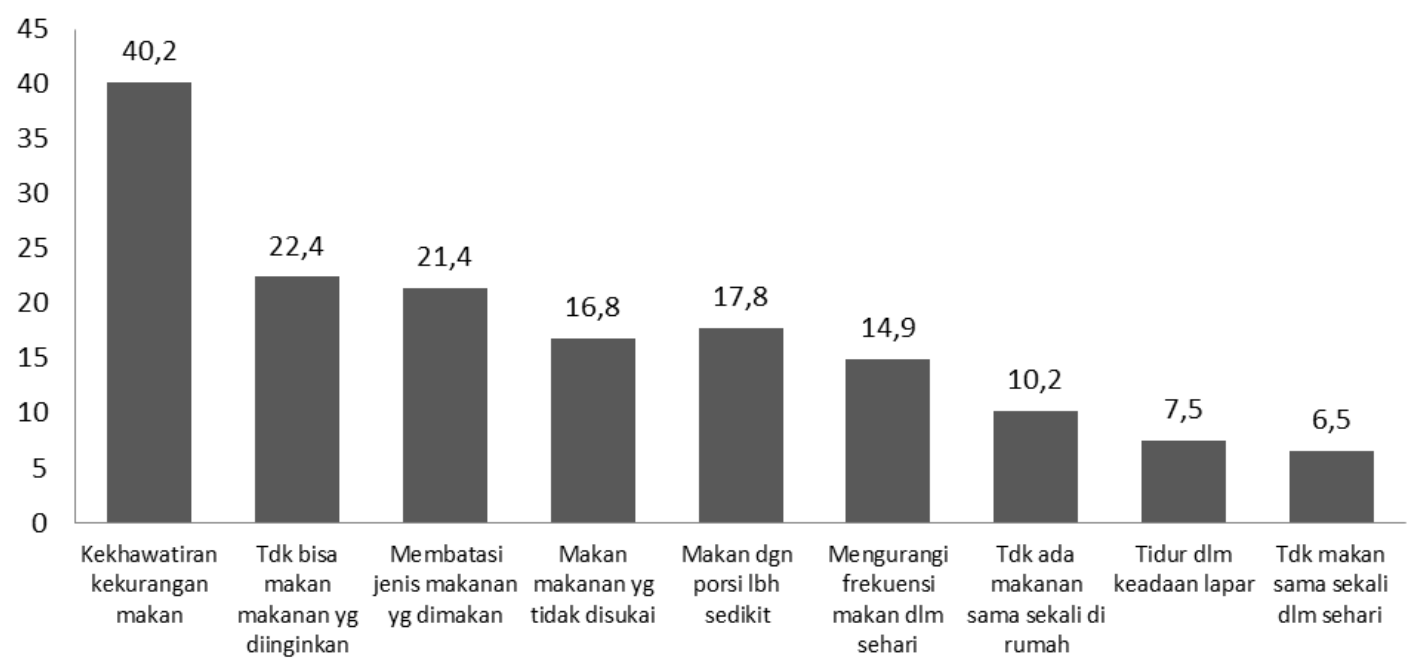

Gambar 2

Sebaran Rumahtangga Responden Berdasarkan Instrumen Ketahanan Pangan (HFIAS) 


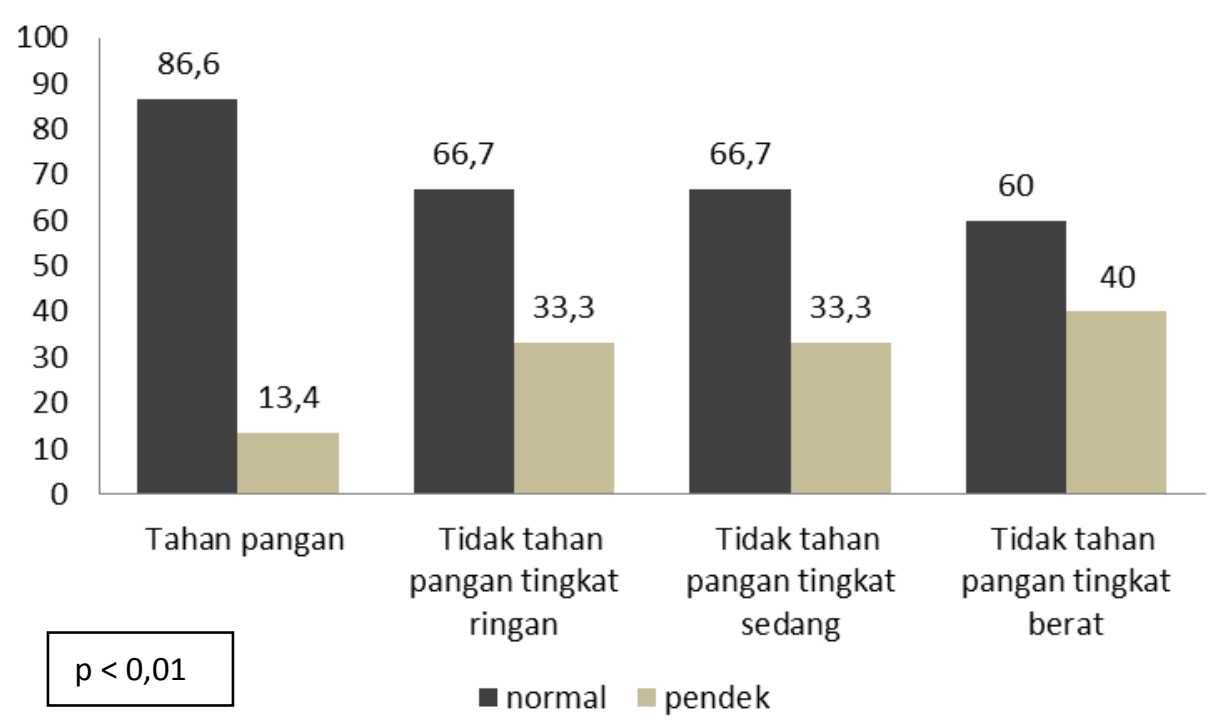

Gambar 3

Sebaran Status Gizi Baduta Berdasarkan Tingkat Ketahanan Pangan Rumah Tangga

Tabel 1

Karakteristik Baduta dan Rumah Tangga Berdasarkan Status Gizi Baduta

\begin{tabular}{|c|c|c|c|}
\hline \multirow{2}{*}{ Variabel } & \multicolumn{2}{|c|}{ Status Gizi } & \multirow{2}{*}{$p$ value } \\
\hline & Normal & Pendek & \\
\hline \multicolumn{4}{|l|}{ Karakteristik baduta } \\
\hline Usia & & & 0,259 \\
\hline 6-11 bulan & $33(84,6)$ & $6(15,4)$ & \\
\hline $12-23$ bulan & $52(75,4)$ & $17(24,6)$ & \\
\hline Jenis Kelamin & & & 0,830 \\
\hline Laki-laki & $54(84,4)$ & $10(15,6)$ & \\
\hline Perempuan & $31(70,5)$ & $13(29,5)$ & \\
\hline Berat badan lahir & & & 0,168 \\
\hline$<2500$ gram & $4(57,1)$ & $3(42,9)$ & \\
\hline$\geq 2500$ gram & $80(80,0)$ & $20(20,0)$ & \\
\hline Morbiditas 2 minggu terakhir & & & 0,228 \\
\hline Tidak pernah sakit & $13(68,4)$ & $6(31,6)$ & \\
\hline Pernah sakit & $72(80,9)$ & $17(19,1)$ & \\
\hline \multicolumn{4}{|l|}{ Konsumsi baduta } \\
\hline Konsumsi ASI 24 jam yang lalu & & & 0,083 \\
\hline Ya & $54(74,0)$ & $19(26,0)$ & \\
\hline Tidak & $31(88,6)$ & $4(11,4)$ & \\
\hline Penggunaan botol dot setiap hari & & & $0,010^{*}$ \\
\hline Tidak & $41(69,5)$ & $18(30,5)$ & \\
\hline Ya & $44(89,8)$ & $5(10,2)$ & \\
\hline Keragaman makanan & & & 0,242 \\
\hline Baik & $10(90,9)$ & $1(9,1)$ & \\
\hline Sedang & $58(80,6)$ & $14(19,4)$ & \\
\hline Rendah & $17(68,0)$ & $8(32,0)$ & \\
\hline
\end{tabular}




\begin{tabular}{|c|c|c|c|}
\hline Keragaman pola makan & & & 0,696 \\
\hline Baik & $30(83,3)$ & $6(16,7)$ & \\
\hline Sedang & $31(75,6)$ & $10(24,4)$ & \\
\hline Rendah & $24(77,4)$ & $7(22,6)$ & \\
\hline Karakteristik orangtua badut & & & \\
\hline Usia lbu & & & 0,820 \\
\hline$<20$ tahun & $3(75,0)$ & $1(25,0)$ & \\
\hline 20-35 tahun & $64(80,0)$ & $16(20,0)$ & \\
\hline$>35$ tahun & $14(73,7)$ & $5(26,3)$ & \\
\hline Paritas & & & 0,215 \\
\hline$\leq 3$ anak & $79(80,6)$ & $19(19,4)$ & \\
\hline$>3$ anak & $6(60,0)$ & $4(40,0)$ & \\
\hline Pendidikan Ibu & & & 0,349 \\
\hline Tinggi & $10(90,9)$ & $1(9,1)$ & \\
\hline Menengah & $39(81,3)$ & $9(18,8)$ & \\
\hline Rendah & $35(72,9)$ & $13(27,1)$ & \\
\hline Pekerjaan Ibu & & & 0,233 \\
\hline Ibu rumah tangga & $67(76,1)$ & $21(23,9)$ & \\
\hline Bekerja & $18(90,0)$ & $2(10,0)$ & \\
\hline Praktek higiene makanan & & & 0,681 \\
\hline Baik & $14(82,4)$ & $3(17,6)$ & \\
\hline Sedang & $43(75,4)$ & $14(24,6)$ & \\
\hline Kurang baik & $28(82,4)$ & $6(17,6)$ & \\
\hline Tingkat pengetahuan gizi ibu & & & 0,263 \\
\hline Baik & $16(66,7)$ & $8(33,3)$ & \\
\hline Sedang & $46(82,1)$ & $10(17,9)$ & \\
\hline Rendah & $23(82,1)$ & $5(17,9)$ & \\
\hline Pendidikan ayah & & & 0,302 \\
\hline Tinggi & $16(88,9)$ & $2(11,1)$ & \\
\hline Menengah & $39(79,6)$ & $10(20,4)$ & \\
\hline Rendah & $27(71,1)$ & $11(28,9)$ & \\
\hline Pekerjaan ayah & & & 0,301 \\
\hline Pegawai Swasta & $42(84,0)$ & $8(16,0)$ & \\
\hline Wiraswasta & $15(71,4)$ & $6(28,6)$ & \\
\hline Buruh & $11(64,7)$ & $6(35,3)$ & \\
\hline Lainnya & $15(83,3)$ & $3(16,7)$ & \\
\hline
\end{tabular}

${ }^{*} p<0,05$

Tabel 2 menyajikan hasil pemodelan ketahanan pangan sebagai risiko pendek pada baduta. Pada model awal seluruh variabel yang diduga berhubungan dengan terjadinya pendek pada anak baduta dimasukkan ke dalam model. Variabel dengan $p>0,05$ satu per satu dikeluarkan sambil melihat perubahan $\mathrm{OR}$ variabel ketahanan pangan rumah tangga sebagai variabel utama. Jika perubahan $\mathrm{OR}$ variabel utama lebih besar dari \pm 10 persen maka variabel tersebut tidak dikeluarkan dari model, karena variabel dianggap sebagai variabel pengganggu dan tetap harus ada dalam model. Pada model akhir dapat diketahui bahwa ketahanan pangan rumah tangga merupakan risiko terhadap kejadian pendek pada baduta, dimana anak baduta dengan keluarga yang tidak tahan pangan memiliki risiko sebesar 10,9 kali menjadi pendek setelah dikoreksi oleh usia anak, berat lahir, konsumsi ASI, penggunaan dot, keragaman makanan, usia ibu, pendidikan ibu, pengetahuan gizi ibu, praktek higiene makanan, pendidikan ayah serta pekerjaan ayah. 
Tabel 2

Pemodelan Ketahanan Pangan Rumah Tangga Sebagai Risiko Pendek pada Baduta

\begin{tabular}{|c|c|c|c|}
\hline Pemodelan & $\begin{array}{c}\text { OR } \\
(95 \% \text { Cl) Crude }\end{array}$ & $\begin{array}{l}\text { OR (95\% Cl) } \\
\text { Adjusted }\end{array}$ & $\begin{array}{c}\text { \% Perubahan } \\
\text { OR Variabel } \\
\text { Utama }\end{array}$ \\
\hline $\begin{array}{l}\text { Ketahanan pangan rumah tangga, } \\
\text { usia anak, jenis kelamin anak, berat } \\
\text { lahir, morbiditas anak, konsumsi ASI, } \\
\text { penggunaan dot, keragaman makanan, } \\
\text { keragaman pola makan, usia ibu, } \\
\text { paritas ibu, pendidikan ibu, pekerjaan } \\
\text { ibu, pengetahuan gizi ibu, praktek } \\
\text { higiene makanan, pendidikan ayah, } \\
\text { pekerjaan ayah }\end{array}$ & $11,9(1,8-76,8)$ & & \\
\hline $\begin{array}{l}\text { Ketahanan pangan rumah tangga, } \\
\text { usia anak, jenis kelamin anak*, berat } \\
\text { lahir, morbiditas anak, konsumsi ASI, } \\
\text { penggunaan dot, keragaman makanan, } \\
\text { keragaman pola makan, usia ibu, } \\
\text { paritas ibu, pendidikan ibu, pekerjaan } \\
\text { ibu, pengetahuan gizi ibu, praktek } \\
\text { higiene makanan, pendidikan ayah, } \\
\text { pekerjaan ayah }\end{array}$ & & $12,1(1,9-78,4)$ & 1,7 \\
\hline $\begin{array}{l}\text { Ketahanan pangan rumah tangga, } \\
\text { usia anak, berat lahir, morbiditas anak, } \\
\text { konsumsi ASI, penggunaan dot, } \\
\text { keragaman makanan, keragaman pola } \\
\text { makan*, usia ibu, paritas ibu, }^{*} \text { pendidikan ibu, pekerjaan ibu, } \\
\text { pengetahuan gizi ibu, praktek higiene } \\
\text { makanan, pendidikan ayah, pekerjaan } \\
\text { ayah }\end{array}$ & & $11,7(1,8-74,5)$ & 1,7 \\
\hline $\begin{array}{l}\text { Ketahanan pangan rumah tangga, } \\
\text { usia anak, berat lahir, morbiditas } \\
\text { anak*, konsumsi ASI, penggunaan dot, } \\
\text { keragaman makanan, usia ibu, paritas } \\
\text { ibu, pendidikan ibu, pekerjaan ibu, } \\
\text { pengetahuan gizi ibu, praktek higiene } \\
\text { makanan, pendidikan ayah, pekerjaan } \\
\text { ayah }\end{array}$ & & $12,2(1,9-78,7)$ & 2,5 \\
\hline $\begin{array}{l}\text { Ketahanan pangan rumah tangga, } \\
\text { usia anak, berat lahir, konsumsi ASI, } \\
\text { penggunaan dot, keragaman makanan, } \\
\text { usia ibu, paritas ibu, pendidikan ibu, } \\
\text { pekerjaan ibu*, pengetahuan gizi ibu, } \\
\text { praktek higiene makanan, pendidikan } \\
\text { ayah, pekerjaan ayah }\end{array}$ & & $12,1(1,9-77,1)$ & 1,7 \\
\hline $\begin{array}{l}\text { Ketahanan pangan rumah tangga, } \\
\text { usia anak, berat lahir, konsumsi ASI, } \\
\text { penggunaan dot, keragaman makanan, } \\
\text { usia ibu, paritas ibu*, pendidikan ibu, } \\
\text { pengetahuan gizi ibu, praktek higiene }\end{array}$ & & $10,9(1,8-67,3)$ & 8,4 \\
\hline
\end{tabular}


makanan, pendidikan ayah, pekerjaan

ayah

\section{Model Akhir \\ Ketahanan pangan rumah tangga,}

usia anak, berat lahir, konsumsi ASI, penggunaan dot, keragaman makanan, usia ibu, pendidikan ibu, pengetahuan gizi ibu, praktek higiene makanan, pendidikan ayah, pekerjaan ayah

* dikeluarkan dari model $(p>0,05)$

\section{BAHASAN}

Hasil studi menunjukkan bahwa sebagian dari rumah tangga responden telah mengalami ketidaktahanan pangan. Dari 3 domain utama yang dinilai dari instrumen HFIAS yaitu kecemasan dan ketidakpastian akan persediaan makanan di rumah tangga, rendahnya kualitas (termasuk variasi dan pilihan) makanan di rumah tangga dan kekurangan asupan makan serta konsekuensi fisik yang terjadi pernah dialami oleh beberapa rumah tangga di Kelurahan Kebon Kalapa. Hasil ini tentunya akan dapat memberikan informasi yang penting mengingat bahwa data mengenai tingkat ketahanan pangan rumah tangga di Kelurahan Kebon Kalapa belum pernah dibahas dalam penelitian-penelitian sebelumnya. Kelurahan Kebon Kalapa merupakan salah satu lokasi penelitian di Kecamatan Bogor Tengah yang sering menjadi lokasi penelitian khususnya adalah penelitian-penelitian kesehatan.

Berbeda dengan hasil studi ini yang mengukur ketahanan pangan rumah tangga dengan menggunakan instrumen HFIAS, studi lain telah mengukur tingkat ketahanan pangan rumah tangga di Kota Bogor dengan menggunakan indikator konsumsi energi dan protein. Dengan menggunakan indikator konsumsi energi kurang dari 70 persen sebanyak 40 persen rumah tangga di Bogor tergolong rawan pangan. Sedangkan dengan menggunakan indikator konsumsi protein kurang dari 70 persen sebanyak 42,4 persen rumah tangga di Bogor tergolong rawan pangan. Jika menggunakan indikator konsumsi energi kurang dari 70 persen dan protein kurang dari 70 persen maka sebanyak 43,5 persen rumah tangga di Bogor mengalami kerawanan pangan. ${ }^{11}$
Ketahanan pangan sebagaimana didefinisikan oleh USAID yaitu keadaan di mana "semua orang setiap saat harus memiliki akses baik secara fisik dan ekonomi terhadap pangan yang cukup untuk memenuhi kebutuhan diet mereka untuk kehidupan yang produktif dan sehat ". Karena merupakan sebuah konsep yang kompleks dan multidimensi, mengukur ketahanan pangan rumah tangga telah menjadi tantangan yang berkelanjutan bagi para peneliti dan praktisi. Sampai sekarang, sebagian besar pengukuran akses makanan rumah tangga, seperti tingkat pendapatan dan kecukupan kalori, secara teknis sulit untuk dilakukan, dataintensif, serta membutuhkan biaya yang cukup besar. ${ }^{10}$

Untuk itu telah diciptakan indikator yang relatif simpel, namun secara metodologi dapat dipertanggungjawabkan untuk mengukur tingkat kerawanan akses pangan rumah tangga yang dapat digunakan untuk memandu, memantau dan mengevaluasi program intervensi yaitu Household Food Insecurity Access Scale (HFIAS). Instrumen ini merupakan adaptasi dari instrumen yang digunakan setiap tahun di Amerika Serikat untuk mengestimasi prevalensi kerawanan pangan rumah tangga. Metode yang digunakan dalam instrumen ini didasarkan pada gagasan bahwa pengalaman kerawanan terhadap akses pangan akan menghasilkan reaksi dan respon yang dapat ditangkap melalui survei. ${ }^{10}$

Hasil studi juga menunjukkan bahwa terdapat kecenderungan dengan semakin baik tingkat ketahanan pangan rumah tangga baduta maka baduta tersebut cenderung tidak pendek. Dimana anak baduta dengan keluarga yang tidak tahan pangan memiliki risiko sebesar 10,9 kali menjadi pendek setelah dikoreksi oleh usia anak, berat lahir, konsumsi ASI, penggunaan dot, keragaman makanan, usia ibu, pendidikan 
ibu, pengetahuan gizi ibu, praktek higiene makanan, pendidikan ayah serta pekerjaan ayah.

Hasil ini sejalan dengan beberapa penelitian sebelumnya. Sebuah studi di Purworejo mendapatkan hasil bahwa terdapat hubungan antara ketahanan pangan tingkat rumah tangga dengan status gizi anak batita (636 bulan). Semakin tinggi skor rata-rata nilai ketahanan pangan maka semakin baik status gizi anak batita. ${ }^{12}$ Hasil lain dari Kabupaten Indramayu menemukan hubungan yang bermakna antara tingkat ketahanan pangan rumah tangga dengan status gizi balita. ${ }^{13}$ Hasil ini sesuai dengan studi sebelumnya di Brazil bahwa anak yang mengalami beberapa level dari ketidaktahanan pangan akan memiliki status gizi yang lebih buruk. ${ }^{3}$

Akan tetapi sebuah studi yang dilakukan di Ghana Utara menyatakan bahwa tidak ditemukan hubungan antara indeks status gizi dengan ketahanan pangan rumah tangga. Studi ini juga menyatakan bahwa ketahanan rumah tangga bukan merupakan indikator yang sensitif untuk anak dibawah usia 24 bulan..$^{14}$ Perbedaan hasil ini mungkin perlu dikaji lebih lanjut. Instrumen yang dikembangkan oleh Amerika Serikat ini bisa jadi harus diadaptasi dan disesuaikan dengan konteks lokal agar dapat menangkap seluruh maksud dari pertanyaan dalam instrumen ini dengan tepat.

Kerawananan pangan rumah tangga telah dikaitkan dengan beberapa masalah kesehatan dan gizi, baik di negara maju maupun di negara berkembang. Kerawanan pangan mempengaruhi secara negatif konsumsi makanan dengan cara mengurangi baik secara kualitas maupun kuantitas makanan, sehingga kerawanan pangan juga dapat memperparah keadaaan gizi. Selain itu kerawanan pangan juga dapat mempengaruhi status gizi melalui efeknya pada stres, depresi, pola pengasuhan dan pemberian makan pada bayi. ${ }^{15}$ Beberapa jalan yang dapat membuat ketidaktahanan pangan dapat mempengaruhi status gizi anak yaitu seperti, pendapatan keluarga. Akan tetapi diantara determinan lainnya, konsumsi makanan merupakan mediator yang terpenting yang dapat menjelaskan hubungan ini. ${ }^{3}$

Kejadian pendek pada anak merupakan bentuk kronis terjadinya kekurangan gizi pada anak. Dari faktor sensitif dan spesifik penyebab terjadinya kekurangan gizi pada anak, maka faktor sensitif lah yang lebih berperan terhadap terjadinya pendek pada anak. Untuk itu penguatan sektor pertanian seperti melalui program pertanian yang difokuskan pada pangan tertentu, jaring pengaman sosial, menjaga harga tetap rendah, meningkatkan pendapatan masyarakat dengan cara memberdayakan perempuan, serta tetap menjaga tersedianya pangan yang beragam di masyarakat sangatlah penting karena dapat berkontribusi terhadap ketahanan pangan keluarga. Untuk itu diperlukan peran serta juga dari sektor lain diluar sektor kesehatan untuk dapat mengatasi permasalahan pendek pada anak.

\section{SIMPULAN DAN SARAN}

\section{Simpulan}

Studi ini menyimpulkan bahwa ketahanan pangan rumah tangga merupakan risiko terhadap kejadian pendek pada baduta, dimana anak baduta dengan keluarga yang tidak tahan pangan memiliki risiko sebesar 10,9 kali menjadi pendek setelah dikoreksi oleh usia anak, berat lahir, konsumsi ASI, penggunaan dot, keragaman makanan, usia ibu, pendidikan ibu, pengetahuan gizi ibu, praktek higiene makanan, pendidikan ayah serta pekerjaan ayah.

\section{Saran}

Pentingnya ketahanan pangan rumah tangga dalam pembentukan sumberdaya manusia yang berkualitas, tidak bermasalah kesehatan dan gizi menuntut peran serta dari seluruh pihak, termasuk diluar sektor kesehatan. Untuk itu diperlukan kesadaran bersama untuk memperbaiki keadaan dan memperkuat ketahanan pangan rumah tangga.

\section{RUJUKAN}

1. Shekar M. Repositioning nutrition as the central of development: A strategy for large scale action. World bank, 2006. Washington DC.

2. Trihono, Atmarita, Tjandrarini $\mathrm{DH}$, Irawati $\mathrm{A}$, Utami NH \& Nurlinawati I. Pendek (Stunting): Masalah dan Solusinya di Indonesia. Badan Penerbit Litbangkes, Jakarta. 2015. 
3. Dos Santos LP \& Gigante DP. Relationship between food insecurity and nutritional status of Brazilian children under the age of five. Rev Bras Epidemiol 2013: 16 (4) 98494

4. Lwanga S, Lemeshow S. Sample Size Determination in Health Studies. Geneva: WHO; 1991.

5. Ruel MT, Menon P. Child Feeding Practices Are Associated with Child Nutritional Status in Latin America : Innovative Uses of the Demographic and Health Surveys 1,2 . Journal of Nutrition. 2002;(October 2001):1180-7.

6. Sawadogo PS, Martin-pre Y, Savy M, Kameli Y, Traissac P, Traore AS, et al. An Infant and Child Feeding Index Is Associated with the Nutritional Status of 6to 23-Month-Old Children in Rural Burkina Faso 1. Journal of Nutrition. 2006;(December 2005):656-63.

7. Arimond M, Ruel MT. Summary Indicators for Infant and Child Feeding Practices: An Example from the Ethiopia Demographic and Health Survey 2000 (pub. 2002). 2002.

8. Fahmida $U$, Dillon $D$. Principles of Nutritional Assessment. Jakarta: SEAMEO TROPMED RCCN University of Indonesia; 2007.

9. Gibson R. Principles of Nutritional Assessment. Oxford University Press; 2005.

10. Coates, J, Swindale A and Bilinsky P. Household Food Insecurity Access Scale (HFIAS) for

Measurement of Household Food Access: Indicator Guide (v. 3). Washington, D.C.: Food and Nutrition Technical Assistance Project, Academy for Educational Development, August 2007.
11. Sukandar D, Khomsan A, Riyadi $H$, Anwar F \& Eddy S. Studi Ketahanan Pangan Pada Rumah Tangga Miskin dan Tidak Miskin. Gizi Indonesia 2006, 29 (1): 22-32.

12. Falupi LA. Ketahanan pangan tingkat rumah tangga dengan status gizi anak batita usia 6-36 bulan di Kabupaten Purworejo. Tesis IImu Kesehatan Masyarakat Universitas Gadjah Mada. 2009

13. Rohaedi, S. Hubungan Antara Tingkat Ketahanan Pangan Rumah Tangga Dengan Status Gizi Balita Pada Rumah Tangga Di Daerah Rawan Pangan Kabupaten Indramayu. Tesis IImu Kesehatan Masyarakat Universitas Gadjah Mada. 2012

14. Saaka M \& Osman SM. Does Household Food Insecurity Affect the Nutritional Status of Preschool Children Aged 6-36 Months?. Hindawi Publishing Corporation International Journal of Population Research, Volume 2013, Article ID 304169, 12 pages.

15. Chaparro, C. Household Food Insecurity and Nutritional Status of Women of Reproductive Age and Children under 5 Years of Age in Five Departments of the Western Highlands of Guatemala: An Analysis of Data from the National Maternal-Infant Health Survey 2008-09 of Guatemala. Washington, DC: FHI 360/FANTA-2 Bridge. 2012

16. Ruel $M$ \& Alderman $H$. Nutrition-sensitive interventions and programmes: how can they help to accelerate progress in improving maternal and child nutrition?. The Lancet Volume 382, No. 9891, p536551, 10 August 2013. Diunduh dari http://www.thelancet.com/journals/lancet/art icle/PIIS0140-6736(13)60843-0/abstract 